\title{
What Is the Question to which Anti-Natalism Is the Answer?
}

\section{Nicholas Smyth ${ }^{1}$ (D)}

Accepted: 16 February 2020 / Published online: 24 February 2020

(C) Springer Nature B.V. 2020

\begin{abstract}
The ethics of biological procreation has received a great deal of attention in recent years. Yet, as I show in this paper, much of what has come to be called procreative ethics is conducted in a strangely abstract, impersonal mode, one which stands little chance of speaking to the practical perspectives of any prospective parent. In short, the field appears to be flirting with a strange sort of practical irrelevance, wherein its verdicts are answers to questions that no-one is asking. I go on to articulate a theory of what I call existential grounding, a notion which explains the role that prospective children play in the lives of many would-be parents. Procreative ethicists who want their work to have real practical relevance must, I claim, start to engage with this markedly first-personal kind of practical consideration.
\end{abstract}

Keywords Anti-Natalism · Moral Philosophy · Existentialism · Meaning of Life · David Benatar · Applied Ethics

Often we can best understand the nature and significance of a philosophical theory by getting clear on the question it is meant to answer. ${ }^{1}$ Here, for example, are some questions that moral philosophers might help us to answer:

1. Which actions should I take?

2. Which actions of mine will best promote valuable outcomes?

3. Which types of actions will best promote valuable outcomes?

4. What are the most valuable outcomes?

\footnotetext{
${ }^{1}$ I owe this more general idea to R.G. Collingwood, who believed that propositions are not fully understood unless seen in light of the questions they are meant to answer. See (Collingwood 1939, pp. 25-43).
}

\section{Nicholas Smyth}

nick.a.smyth@gmail.com

1 Fordham University, Collins Hall, Rose Hill, Bronx, NY 10458, USA 
These questions are prima facie distinct, and it would require substantive argument to show that two of them are, contrary to appearances, identical. They lie on a familiar continuum that begins with practical inquiry conducted from within a first-personal, situated perspective and ends with a detached, theoretical inquiry into which possible world is the best one.

In this paper, I will argue that a wide range of positions in procreative ethics may well be of no practical relevance to people who are deliberating about whether to procreate. This is because these positions are primarily answers to the third and fourth types of question, and because their authors have not even tried to connect those answers to the first-personal, deliberative question of how an agent should think about her decision to have children. I will not argue that this gap cannot be bridged, but I will stress that this is a serious collective failing, one that needs remedying if procreative ethics is to be anything more than a mere philosopher's game.

Along the way, I will develop an account of what has been rather unfortunately termed "the right to procreate" (Cutas 2009; Quigley 2010; Robertson 1996). On my account, there is in fact no such right or permission, as these deontic concepts do not capture the normative significance of procreation in an individual human life. Rather, I will argue, a person's reasons to procreate are often profoundly subjective and existential, located in a normative space that is distinct from the domain of objective morality.

\section{Practicality and Authority in Moral Philosophy}

One of the controlling ideas of late-twentieth century philosophical ethics was that there is certain tension between two competing practical perspectives. Thomas Nagel, Susan Wolf, Bernard Williams, and Christine Korsgaard each offered subtle and powerful discussions of this idea. Nagel said that we are torn between the "objective" and "subjective" perspectives on values and action, Williams argued that moral philosophy tends to distort the affect-laden "inside" perspective on action, Wolf argued that life's meaningfulness is contingent on our balancing something like these "inside" and "outside" perspectives, and Christine Korsgaard argued that ethical truth is only accessible from the standpoint of actual decision-making, and not from a detached, theoretical standpoint. $^{2}$

Each of these thinkers grappled with the evident fact that our ethical lives are stretched on a wire, running between a reflective, impersonal and broadly impartial viewpoint and an engaged, partial, subjectively rich, largely unreflective viewpoint. Each took a different stance on the ultimate nature and significance of this fact, but each believed that it was of great importance. And importantly, each drew the conclusion that the first question listed above - which I will call the practical question - cannot not be answered simply by listing some set of impartially generated truths about valuable outcomes or possible worlds. The idea that morality (so conceived) can accomplish this feat is, they argued, akin to a kind of metaphysical fantasy. Since agents must form intentions if they are to decide what to do, we must have some account of how a series of facts is related to an agent's practical perspective, such that an encounter with those facts could produce intentions to act. This, in a nutshell, is the practicality problem for ethics: what is the relation between moral

$\overline{2}$ See (Korsgaard 1996; Nagel 1989; Williams 1985; Wolf 1997). For a canonical discussion of this general issue, see (Scheffler 1994) 
considerations and the actual intentions of rational human agents? How can we act on those considerations? ${ }^{3}$

Moreover, as Williams and Korsgaard stressed, even if we solve this perennial problem, there is a second question, that of rational authority. An agent may care about being a morally good person, and certain moral considerations may connect up in the right way with their practical perspectives. But this does not entail that they always ought to prioritize those considerations over other ones, nor does it even entail that they ought to give those considerations very much weight at all. This is what I will call the authority problem: why do the dictates of an impartial moral perspective trump reasons arising from other viewpoints? ${ }^{4}$

In what follows, I will assume that any moral philosopher who supplies us with moral verdicts must provide a substantive solution to the practicality and authority problems. Unfortunately, I lack the space to defend this general meta-ethical orientation. The position is hostile to certain forms of externalist moral realism which hold that practical reasons might simply be facts simpliciter, and that such facts might fail to motivate any agents and still retain their normative status (Parfit 2011; Scanlon 2014). Proponents of this view tend to relegate the practicality problem to the domain of psychology; the question of how reasons motivate actual agents is simply not part of the program. Realists of this sort might remain justifiably unmoved by the arguments I provide in this paper, though I will suggest that this position comes at a cost. A moral realist who wants to reject my arguments must think of applied ethics as a very strange field, one which supplies verdicts to real persons but which does not think that any persons are meant to act on those verdicts. This is a coherent position, but as I will suggest, it requires us to radically re-conceptualize applied ethics.

Thus, I will mostly follow Korsgaard, Williams, Nagel and Wolf in assuming that any philosopher who produces substantive moral verdicts - an applied ethicist, for example — must address the practicality and authority problems. Moreover, it seems clear enough that our ability to solve the practicality and authority problems depends on the way we generate our moral verdicts: if the procedure is not one that an actual decision-maker can recognize and incorporate into their lives, then the verdict simply cannot gain the right sort of traction.

\section{The Impersonality of Procreative Ethics}

Consider, then, contemporary procreative ethics, where (as I will shortly show) a great many philosophers write as though the questions of practicality and authority are virtually settled by the mere declaration that biological procreation is morally suspect in some impersonal, objective sense. ${ }^{5}$

\footnotetext{
${ }^{3}$ The question of how reflection on ethical propositions can issue in intentions was most influentially articulated by Aristotle. In recent meta-ethics, it has come to be known as "the normative question". (Aristotle 2009, p. 1147a; Dreier 2015; Korsgaard 1996) I add the qualifier "rational" in my description because it is not clear that a moral philosopher has to explain how moral considerations can motivate any agent; most philosophers in this area will concede that this explanatory burden only exists for agents who meet certain minimal standards. Even the fairly skeptical Williams granted that an agent may be totally unmoved by their own overriding reasons if they lack certain cognitive or imaginative capacities. (Williams 1981) I am grateful to Mona Simion for discussion of this point.

${ }^{4}$ For various discussions of what has been called the "overridingness" question, see (Archer 2014; Black and Tiffany 2011; Portmore 2008; Stroud 1998; Tanyi 2012; Williams 1981). See also Sam Scheffler's Human Morality, ch.3 (Scheffler 1992).

${ }^{5}$ A principal exception is Christine Overall. The final chapter in her Why Have Children? has the virtue of not automatically treating the moral and the practical questions as though they were identical, and openly discusses meaningfulness, authenticity and identity. (Overall 2012)
} 
In doing so, they follow the contemporary enfant terrible of procreative ethics, David Benatar, whose anti-natalist work is in many ways responsible for the revival of this topic.

\subsection{Benatar's Anti-Natalism}

Benatar has argued that it is always wrong to bring somebody into existence. He has three principal arguments for this conclusion. I will label these the asymmetry argument, the misanthropic argument and the badness of life argument, and I will take each in turn. I will not attack the logic of each argument, rather, I will focus on the type of considerations it brings to bear on the practical question at hand. In each case, I will suggest, such considerations can only seem relevant to procreative decision-making if we blur the lines between distinct practical questions.

To begin, Benatar has argued that "coming into existence, far from ever constituting a net benefit, always constitutes a net harm" (Benatar 2006, 1). In order to establish this, he outlines what he calls the "basic asymmetry":

(1) The presence of pain is bad, and (2) the presence of pleasure is good...However... (3) The absence of pain is good even if that good is not enjoyed by anyone; but (4) the absence of pleasure is not bad unless there is somebody for whom this absence is a deprivation. (Benatar 2006, 30)

This asymmetry, he claims, shows that it is better never to come into existence. Roughly, this is because the absence of pain always counts in favor of not existing, whereas the absence of pleasure never counts against not existing.

Now, Benatar immediately notices that the argument has an undesirably abstract or impersonal flavor. This is because we are meant to place a great deal of weight on an asymmetry in valuation that is said to apply to a person who, by definition, does not exist. As soon as we start to speak of a real, flesh-and-blood person, the proposition (2) will justify their existence, and the asymmetry will no longer hold. Yet, can mere intuitions about badness with respect to non-existent persons really suffice to show that reproduction is necessarily a moral evil? How can the absence of pain count in favor of a decision if there is no-one for whom that absence is good?

As several critics have pointed out, the argument has a deeply impersonal flavor. ${ }^{6}$ This is why, in later work, Benatar is at pains to deny that his comparisons between the absence of pain and the absence of pleasure are impersonal or purely metaphysical. He insists that his conclusion is that "it is better for a person that he never exist, on condition that we understand that locution as a shorthand for a more complex idea."(Benatar 2013, p. 124) Presumably, since prospective parents care about the welfare of their (possible) children, this idea - that it is better for their children to never come into existence-would immediately secure practical relevance for the argument and for Benatar's overall position. But what is this "more complex idea"?

\footnotetext{
${ }^{6}$ See (McMahan 2009).
} 
That more complex idea is this: We are comparing two possible worlds - one in which a person exists and one in which he does not. One way in which we can judge which of these possible worlds is better, is with reference to the interests of the person who exists in one (and only one) of these two possible worlds. Obviously those interests only exist in the possible world in which the person exists, but this does not preclude our making judgments about the value of an alternative possible world, and doing so with reference to the interests of the person in the possible world in which he does exist. (Benatar 2013, p. 125)

It is revealing that Benatar cannot elucidate his allegedly 'personal' claim without saying that we are in fact comparing the values of two possible worlds. Since he cannot say that one possible life is better than another, he must say that one world is better than another. But the question of what is better for a person is not identical (or, we might add, even remotely similar) to the question of which of two worlds is best. Moreover, when asking what would be best for their future children, prospective parents are not asking about the comparative value of two possible worlds. Benatar, despite what he says, is answering the fourth and most abstract of the questions listed at the beginning of this paper. ${ }^{7}$ But this is not the question that any prospective parent is asking, nor has anyone shown that it is the question they ought to be asking.

Let's now consider Benatar's second argument, which he appropriately labels the misanthropic argument. Benatar claims that human beings cause so much suffering that we should not make any more of them. He thinks that "we have a (presumptive) duty to desist from bringing into existence new members of species that cause (and will likely continue to cause) vast amounts of pain, suffering and death." (Benatar and Wasserman 2015, p. 35) What kind of pain and suffering matters, here? When confronted with the fact that human-on-human infliction of suffering has been declining rapidly for centuries, Benatar cites the population explosion in order to insist that it is the total amount of suffering caused by humans, and not our individual contributions to the amount, that really matters (Benatar and Wasserman 2015, 51). Humanity is generally despicable because of the aggregative total suffering it causes, and not because of the suffering that each human being causes.

Many are instinctively repelled by such arguments, perhaps because humanity is cast as some kind of disease or blight, such that intentional procreation becomes morally analogous to the release of malarial mosquitos or smallpox germs into an ecosystem. I want to try to dig beneath this sort of response and ask a prior question about why the perspective Benatar takes is automatically taken to have practical relevance. He is plainly working under ruleconsequentialist assumptions; it is supposed to be wrong to produce children because producing children, in general, results in a great deal of suffering. Yet, as I have already indicated, much of late-twentieth century ethics was devoted to showing that this sort of abstract, aggregative, rule-consequentialist approach faces a barrage of serious objections, mostly centered precisely around the problems of authority and practicality (Hurley 2009). It is entirely unclear why impartially delivered facts about overall global suffering must outweigh other practical considerations for any rational agent, or how we are supposed to relate these facts to the actual decision-making processes of situated human beings. Prospective parents are asking: should $I$ have children? And Benatar's answer, at this stage, is: no, because procreation

\footnotetext{
${ }^{7}$ In saying this, I am not asserting that the badness of a possible-future person's life should never weigh in our deliberations. My argument here merely concerns the form of the comparative question that is being asked: if we are to include such possible-future persons in our deliberation about whether to make them actual, we necessarily compare worlds and not lives.
} 
in general produces a great deal of aggregate suffering. But is this an answer to the question? Only if the aggregate suffering produced by a type of action is a consideration that ought to weigh decisively the first personal performance of a token of that type. But this is, to put it mildly, a highly contentious thesis, one which Benatar never defends. Here, again, it is only by blurring the lines between distinct questions that his desired conclusion can appear plausible.

Finally, Benatar offers the badness of life argument. This argument alleges that any future child is likely to have a life that is on-balance disvaluable for the child. This is because, according to Benatar, there are many kinds of pain and suffering that we suppress, forget, or try to ignore when we try to convince ourselves that life is in fact worth living. Once those negative elements are added to the balance sheet, he thinks it becomes clear that the average life, or possibly all human life, is not worth living (Benatar 2006, 85).

Now, admittedly, this is the sort of consideration which can easily count as practical and authoritative for prospective parents, since virtually no-one wants to create children whose lives contain on-balance suffering or personal disvalue. One can easily imagine saying to an ordinary person: "You're going to create someone that you will love, but that someone is going to have a life full of undeserved pain and suffering." Surely this admonition makes plain sense, so at first glance it can appear as though Benatar is appropriately concerned to relate his position to the practical perspectives of deciding agents.

Unfortunately, this appearance is deceptive. As the argument develops, it immediately relies on an abstraction away from those very practical perspectives, away from the ways in which ordinary reflective agents see their lives. After all, as Benatar well knows, the first question any of us will ask upon being presented with this argument is: "Does my life really seem that bad?" Moreover, unless we are in rather permanent and dire circumstances, we are very likely to say: "no", even after deep, thoughtful reflection. In order to pre-empt this thought-which will severely weaken the badness of life argument-Benatar lists several "biased" tendencies in human self-assessment, for example, the well-known fact that people's assessments of subjective well-being are not particularly affected, in the long-term, by such things as poverty and ill health (Benatar 2006, pp. 65-66). We are, he says, not reliable assessors of our own wellbeing.

I do not wish to completely adjudicate the bias question here; my focus is on the perspective from which these arguments are being launched, and not on their merits or demerits. However, there is a thorny philosophical problem hiding in all-too-easy declarations of bias. Suppose it is true that after falling into serious long-term illness, most people will take about a year to report the same level of well-being they reported before becoming ill. What, exactly, does this show?

One hypothesis is that the illness has permanently reduced their well-being, and if this is so, we can indeed conclude that such people are hopelessly biased in favor of the value of their own lives. This is Benatar's view. But another hypothesis is that the value of a life is not entirely given by the data that we can cite about it from a third-personal perspective. Perhaps well-being is more holistic, depending at least partly on the perspective of the person involved and on the way in which that perspective interacts with and evaluates their own experiences.

Consider a subjectivist, desire-fulfillment view of well-being (Heathwood 2014). Benatar argues that even if this view is true, we tend to ignore or forget about the large number of our desires that go unsatisfied. But desire-satisfaction is not a matter of mere counting. Rather, some desires are more central to our lives and identities, and any plausible desire-satisfaction theory will accord such desires far more weight. Yet, is it not the case that (for example) the desire to be happy with one's life is powerful, controlling, and central to the lives of pretty much everyone? When the person with a long-term illness adjusts to their circumstances and 
regains their sense of contentment, is this powerful desire not thereby being satisfied? This would entail that their life is improving, perhaps dramatically. And if this is so, in what sense is such a person biased against the truth about their lives?

This dialectic is familiar in meta-ethics: subjective accounts of reasons or values partly immunize us against bias by defining the facts in terms of our attitudes (Street 2016). Any broadly subjective account of well-being will have the same feature. But this possibility does not, to my knowledge, receive any treatment in Benatar's work. The idea that coming to feel a certain way about one's life partly constitutes the goodness of that life is alien to his more third-personal mode, which looks instead to such measurable, quantifiable elements as physical or financial health as determinants of well-being. And this argumentative lacuna is exactly what you would expect from a philosopher who is so unconcerned to answer questions about practicality and authority.

Now, in support of the claim that we are biased against the truth about our lives, Benatar sometimes runs a different, even more abstract argument. He has claimed that our inclination to see life as generally good is the product of evolutionary influence, and that this has biased us against the cold reality:

Anti-natalist views, whatever their source, run up against an extremely powerful pronatalist bias. This bias has its roots in the evolutionary origins of human (and more primitive animal) psychology and biology. Those with pro-natal views are more likely to pass on their genes (Benatar 2006, p. 8).

Unfortunately for Benatar, it is now well-understood by those working on evolutionary debunking that the mere fact that we were in some sense bound to arrive at some evaluative orientation, given Darwinian influence, says nothing about the normative status of that orientation. Rather, it is only when the evolutionary influence is shown to positively distort our evaluative outlook that its justification is called into question (Copp 2008; Vavova 2014). But this, of course, requires just the sort of argument that is missing from Benatar's texts: a non-question-begging way of establishing that life actually is bad overall, such that we can positively establish that evolutionary influences have pushed us off-track.

Let's review. The decision to procreate is often made by someone who is intensely engrossed in a series of intimate questions: am I ready for this challenge? Is this the kind of love I can accept into my life? Will I be able to provide care and support for my child? Will this decision alter my relationship with my partner in undesirable ways? Is this the sort of world into which I wish to bring a child? I find it instructive to imagine such a person picking up a book on procreative ethics and reading that this collection of difficult and deeply personal questions can be tossed aside, because:

(1) The absence of pain is good even if that good is not enjoyed by anyone; and the absence of pleasure is not bad unless there is somebody for whom this absence is a deprivation,

(2) Human procreation is causally related to the production of large amounts of suffering, and

(3) Life is bad, but you don't notice that because evolution has made you biased.

It should be clear that there is at least a problem here: how could such abstract, impersonal thoughts have practical authority over the decisions of real agents who are confronted with this important decision? Strikingly, many contemporary procreative ethicists, pro-natalists included, have not even acknowledged that this sort of problem exists. Instead, they have mainly 
followed Benatar in continuing to write in highly impersonal terms about sufferings, harms and duties, usually in impartial and quantitative terms.

\subsection{Other Procreative Ethicists}

In articulating a contrary, pro-natalist position, Elizabeth Brake attempts to outline what is morally significant about procreation. "What can be said in favor of procreation," she asks, "other than preference, instinct, or a desire to continue the family line? Such relatively trivial reasons look unlikely to justify it in the face of its costs...A procreative justification needs to extend beyond the personal project of parenting."(Brake 2015, pp. 140, emphasis mine) Having summarily dismissed the practical perspectives of deciding agents, she goes on to tell us what is most significant about procreation: "Procreation shapes the future by populating it. It is a direct contribution to the gene pool and to the future agents who will make decisions changing the world." Her thought is that in some cases, this contribution will be on-balance valuable. Yet, why should any deciding agent take this consideration - that they might make an extremely miniscule contribution to the impersonal value of future populations - to have practical relevance?

No answer is forthcoming, nor does an answer appear in a great deal of related literature. In articulating a similar position, Anca Gheaus argues that we might have individual pro tanto duties to procreate in order to avoid the scenario in which humanity's final generation "suffer[s] great harm due to depopulation"(Gheaus 2015, p. 87). She follows several writers in arguing that, contra Benatar's misanthropic argument, procreation produces significant public goods. For example, pregnancies ensure that society will contain have a tax base which can fund old-age pensions. Moreover, future children will provide future generations with a working economy which will prevent the human race from suffering a deeply unpalatable death (Gheaus 2015, p. 94). These considerations, she thinks, might be sufficient to generate a defeasible duty to procreate. Yet, the fundamental first-personal question remains: why should any prospective parent see their decision as regulated by these considerations? No answer is forthcoming. ${ }^{8}$

Corey MacIver, in arguing that procreation is as morally criticisable as anything else that affects our ecological footprint, writes that procreation is "a fundamentally material practice, reliant upon the appropriation of significant quantities of natural goods." Roughly, procreation is said to be fundamentally material solely because it requires those natural goods, and MacIver doesn't dwell on the fact that, according to his definition, weddings, churches, blood banks, funeral homes, graveyards and large monuments dedicated to victims of genocide are "fundamentally material". In any case, once the decision to have a child is equated with the decision to appropriate resources from other people without their direct consent, it is easy to conclude, as MacIver does, that "procreative decisions are subject to moral censure and even to intervention." (MacIver 2015, p. 118) Thomas Young goes even further, equating childrearing with what he calls "ecogluttony" solely because he cannot find a way to draw a distinction between having a child and purchasing, for example, "a dozen jet-skies, six jacuzzies, three bars, and an indoor tennis court." (Young 2001, p. 186) As I will suggest in section four, this is a significant failure of imagination.

\footnotetext{
${ }^{8}$ Of course, many parents have children to ensure their own well-being as they enter old age. But this is not the kind of consideration that Gheaus cites. Rather, she focuses solely on the well-being of humanity in general.
} 
Many more examples could be produced. Each of these philosophers names a state of affairs - the relative size of an ecological footprint, the production of valuable genetic material, the overall badness of the average person's life, tax bases, pension plans - and rather startlingly moves from certain possible-future states of affairs to an entirely distinct deontic judgment (that procreation is forbidden, required, or what have you). Once the values of prospective states of affairs have been weighed, and the probabilistic calculations are in, the deontic status of procreation is established, and that is that.

But what is this work for? What is its purpose? Who is supposed to read it, and who is supposed to accept its conclusions about procreation? These questions lead us to a more general problem: what, exactly, is applied ethics supposed to be?

\section{What Is Applied Ethics?}

Consider a slightly unfamiliar model of applied ethics, one which nonetheless harmonizes nicely with the externalist moral-realist position mentioned earlier. We might call this a juridical model, inasmuch as its fundamental goal is to issue verdicts in the form of moral propositions. Moral propositions are facts about reasons. These facts will concern the rightness, wrongness, permissibility or impermissibility of such things as abortion, euthanasia, social inequality, factory farming and stem cell research. And it is perfectly possible that these facts will be abhorrent, incoherent or otherwise mysterious to human beings who must make real-world decisions.

Unsurprisingly, some realist philosophers simply deny that moral philosophy is practical in the sense I have been discussing, and this view commits them, fairly inexorably, to the juridical model of applied ethics. "If moral philosophy had the aim of answering such [practical] questions," writes arch-externalist Derek Parfit, "it could not possibly succeed. Moral philosophy cannot make our decisions" (Parfit 2011, pp. Vol II, 415). For these philosophers, moral philosophy simply aims at theoretical discovery, an activity which may quell various metaphysical worries but which is not actually meant to help us decide anything. Indeed, if the task of procreative ethics is simply to register these facts, to note their existence on some cosmic ledger, then perhaps that task has been accomplished by the procreative ethicists I am discussing.

However, this is not at all what applied ethics appears to be, and most work on the function of applied ethics has concluded that it is in fact meant to help us make decisions. ${ }^{9}$ It's not hard to see why. Consider what is widely considered to be the most important and influential work in applied ethics, Peter Singer's Animal Liberation (Singer 1975). While sometimes pitched as an application of utilitarianism to the question of animal rights, the book's social importance is plainly not due to its adherence to any moral theory. Rather, its arguments resonated deeply with the practical perspectives of millions of readers. The frank discussions of animal suffering and anguish, the charges of 'speciesism', and the final, passionate call to action - this was applied ethics that was meant to move us in the right direction. In a retrospective interview, Singer himself says as much:

\footnotetext{
${ }^{9}$ For example, The Journal of Medicine and Philosophy published an entire issue on methodology in applied ethics in 2000. While the authors differed in many respects, the editor noted that every contributor to the issue shared the assumptions that "bioethics is about resolving cases, not about moral theory, and that the best method of bioethical decision-making is that which produces useful answers." (Smith Iltis 2000)
} 
When I wrote it, I really thought the book would change the world. I know it sounds a little grand now, but at the time the sixties still existed for us. It looked as if real changes were possible, and I let myself believe that this would be one of them (Specter 1999).

He was right, of course. His book did change the world, because it provided considerations that helped millions of actual people to make firm decisions regarding their own consumption of meat.

Now, if the task of reproductive ethics is what it appears to be - to help actual people make the best reproductive decisions available - then questions about the authority and practicality of global, impersonal value-balancing cannot be avoided. Because they do not directly say what their work is meant to accomplish, I cannot say what Benatar and his fellow procreative ethicists would say here. But at this point I can register a conclusion: if the question to which various natalisms are an answer is merely that of the content of that cosmic ledger, then these natalisms are a distinctly odd, juridical form of applied ethics which is not actually meant to be applied by anyone. They are territory staked out in a chess match that moral philosophers are playing with each other, and they do not tell anyone how to think about their own decisions (Dennett 2006). ${ }^{10}$

Perhaps, however, something more interesting and ambitious is intended. Perhaps it is that thoughtful people, in reading these discussions, are meant to be supplied with authoritative practical reasons for accepting some conclusion or another. These are supposed to be reasons that resonate with readers, just as profound animal suffering resonated with Singer's readers. Now, my main critique returns with a vengeance. For, as was the case with Benatar's arguments, there is a striking gap between the considerations provided by Brake, Gheaus and MacIver and the practical perspectives of actual agents.

Consider the most familiar way to illustrate the gap, which begins with the well-known fact that we, as individual persons, are powerless to affect the large-scale social and environmental ills listed by authors like Brake. These are the "costs" she worries about which, she suggests, dramatically outweigh my personal desires or projects. It is supposed to be wrong for me to have children because I am increasing my ecological footprint, but the smallness of that footprint relative to the scope of the ecological problems facing humanity is so extreme that it is hard to analogize. To call it even a 'drop in the bucket' is to give my offspring's expected ecological footprint far too much significance, whether I have one child or ten.

This is a particularly stark way in which these natalisms fail to relate their evaluative conclusions to the practical perspectives of real agents. Individual decision-making is illicitly absorbed into the collective, such that each decision-maker is somehow made responsible for outcomes they have virtually no hand in producing. If my remaining childfree will not in any way deter ecological disaster, then ecological disaster is not immediately relevant to my remaining childfree. I do not wish to argue that it couldn't be shown to be relevant; after all, there is always recourse to rule-utilitarianism, should any of these philosophers with to adopt that view (and show how it is practical and authoritative). I merely want to note the strange fact

\footnotetext{
${ }^{10}$ Perhaps more charitably, these philosophers may be offering arguments in favor of certain state policies, such as China's well-known one-child policy. If this is so, then they should be far more explicit about this, and drop any references to moral censure and blame, to rightness, wrongness, permissibility or impermissibility. If, for example, MacIver's point is simply that governments have strong reasons to discourage reproduction, reasons grounded in resource-scarcity, then he should simply say so, and not insist that procreators are subject to "moral censure".
} 
that many procreative ethicists do not, as a rule, acknowledge the existence of this famous gap between global disvalue and individual decision-making.

One way to summarize what has been said is to say that there are more and less personal ways to do ethics. It will be said, rightly, that moral philosophy cannot be wholly personal. The activity of philosophy requires a certain abstraction and reflective distance from situational particulars. ${ }^{11}$ Be that as it may, each successive step toward abstraction leaves something behind, and my diagnosis is that each step leaves us successively less able to answer questions about practicality and authority.

What kind of compromise between the general and the particular can a moral philosopher strike, here? Consider the position adopted by Martha Nussbaum on this question. She argues that literature can play a powerful role in moral philosophy, and as if she is right, a moral philosophy which drew heavily on literary examples would almost certainly count as personal philosophy in my sense, and would thus be well positioned to solve the practicality problem (Nussbaum 1990). If the deliverances of such a moral philosophy can be made to resonate with the reader via their sympathetic identification with a character's perspective, then it may be able to effect a transformation in the reader themselves. If such a philosophy has done well, then the reader may now care about the claims being endorsed and may be more inclined to see those claims as authoritative.

Now, my own view is that non-fiction is an equally powerful and under-appreciated resource for moral philosophers. Autobiographical writing, for example, can illuminate the contours of lived human experience, offering a window into practical considerations which are actually salient to real agents. One such consideration is worth dwelling on here, as it is deeply relevant to the question of procreation and is often ignored by writers whose gaze is so firmly fixed on the abstract, impersonal realm of deontic verdicts. ${ }^{12}$ I call it existential grounding. In order to see what existential grounding is, it will be necessary to move away from pure theory and engage directly with lived experience.

\section{Existential Grounding}

Consider a simple, everyday scenario. A woman arrives home with her groceries, unpacking them and putting them away, and leaving out the ingredients for a vinegarchicken recipe she wishes to try. After turning on some of her favourite music, she quickly enters the flow of the kitchen, dicing, frying and spicing as the recipe directs. The meal is cooked, and she sits down with a glass of white wine and a plate of food, breathing it all in, unreflectively savouring the particular atmosphere that is this moment with this dish and this music in this life.

Memories of such particular experiences are what leap unbidden into our minds when we encounter certain sounds or smells, when a sensory modality triggers a cascading tide of recollection, transporting us back to a unique time in our lives which was not necessarily good or bad but which was simply us. Such memories supply many of us with narratival continuity, they remind us of our temporally extended existence, and their

\footnotetext{
${ }^{11}$ This is roughly the tension to which Williams was referring when he said: "We can dream of a philosophy that would be thoroughly truthful and honestly helpful. This, of course, implies an impossible combination of characteristics." (Williams 2000, 212).

12 Once again, I wish to explicitly exempt Christine Overall from this criticism.
} 
passing subtly reminds us that ultimately our time on this earth will someday come to an end. $^{13}$

Such experiences are not readily describable in the hedonistic categories to which Benatar so often reduces human experience. Rather than directly deploy predicates like "pleasurable", we might approach the problem by following those existentialist philosophers who claim that only our consciousness of death can illuminate the meaning of our life. ${ }^{14}$ We might, in other words, ask the following question:

Suppose I am on my deathbed in a number of years, reflecting back on the point or purpose of my life. Suppose further that I decide that it has all been worth it. Is this the sort of experience which I would cite as part of a justification for that judgment?

If the answer is a resonant and wholehearted 'yes', then the experience is, for a person, existentially grounding. ${ }^{15}$ While its significance is potentially shareable, its function is not primarily to justify one's actions to others. Rather, its function is to justify one's life to oneself, to the person who must actually live it. I have deliberately chosen an example that may seem trivial, one that may induce some to wonder why I would ever include something so mundane as an evening's cooking in a paper about moral philosophy. But that is precisely the point: to the person having the experience it may be quite serious indeed, and its triviality to you, the analytically disengaged reader, is neither here nor there. It is not meant for you, because it is not an answer to any question that you are currently asking. ${ }^{16}$

Now, to the point: I think it is eminently clear that procreation - the project of conceiving, birthing and raising a child - is existentially grounding for many or even for most people who decide to undertake it. ${ }^{17}$ In defense of this claim, I can only say that it is what shines out of autobiographical language like this:

It's a bittersweet process, the changing of the seasons. The switch itself is beautiful - the fire in the trees, the long shadows on the ground, the harvest sunsets, the cool air on sunburned skin... That spark, that first orange leaf, always makes me feel sad. I tend to start missing things before they're gone. At least, I think to myself as I watch the burnt

\footnotetext{
${ }^{13}$ According to Galen Strawson, narratival continuity is not a universally shared human experience, and I am perfectly willing to grant that these descriptions won't resonate with everyone (Strawson 2004). However, this is dialectically irrelevant here. Procreative ethicists argue over whether procreation is right or wrong as such, and these positions are rendered problematic even by the existence of some people whose lives are such that they have strong practical reasons to procreate.
}

\footnotetext{
${ }^{14}$ Most notable here is Heidegger; see (Edwards et al. 1979; Heidegger 1996). .

${ }^{15}$ I use the terms "resonant" and "wholehearted" in roughly the sense given to them by Harry Frankfurt in his important work on identity and autonomy. See (Frankfurt 1987).

${ }^{16}$ I am thus in agreement with Nomy Arpaly's critique of Susan Wolf's account of life's meaningfulness. Wolf includes an "objective" component in her account, which is meant to rule out the meaningfulness of lives which, for example, entirely revolve around the love for a goldfish. Arpaly simply asks: why isn't such a life meaningful for the person who is living it? Here, we may simply distinguish two questions. Is this a life we would wish to lead, or that we would wish for our loved ones to lead? The answer is probably 'no'. But is this a life that is existentially grounding for the goldfish-lover? The answer is 'yes' (Wolf et al. 2010).

${ }^{17}$ Curiously, in his most recent work, Benatar recognizes that something like this is true. He writes: "Many people have meaningful lives from this perspective. They are loved and cherished by their family, and in turn they play important, meaningful roles in the lives of those family members. They provide love, support, company, and deep personal connections."(Benatar 2017, p. 28) He does not seem to recognize that this complicates his anti-natalist position.
} 
leaves fall, summer will come around again. Life is, after all, a very cyclical kind of thing.

It's 7:00 PM and I'm snuggled up in a rocking chair with my son under a green and yellow knitted baby blanket that used to belong to his dad. The fire...fills the room with a warm amber light that shifts on the walls and plays on the pages of the book open in front of us...

Someday these leaves will burn up and he'll be a kid who goes to school, and I'll miss him — but he'll be ok. It will be another new beginning, another spring. Someday he won't live in my house anymore, but maybe he'll meet someone special and start a family. And then maybe, the moment he lays eyes on his own baby, he'll catch a glimpse into how I feel about him. That will be another spring. (Krause 2017)

Krause uses plain language to express something with which many of us are familiar: that sense of change, decay and inevitable loss we can feel as the seasons change. Moreover, for her, the decision to procreate represents her redemptive participation in an ancient and apparently sacred cycle. Her life has presented her with an unavoidable question: how can I make sense of loss and change? And her son is, in many ways, an answer to that question. And this, by the way, is a question which has plainly been of enormous practical urgency for people throughout human history. ${ }^{18}$

In any case, this is the narrative into which she places her son's existence. He is how she makes peace with change, decay and loss. Her words may resonate with some readers; if so, this passage can help to illuminate existential reasons they share with Krause. Others will find her perspective maudlin, sentimental or even silly. But this is perfectly compatible with my main claim, since her experience is existentially grounding for her and no one else. Moreover, there is something odd, perhaps even downright absurd, in expecting first-personal reflections on a life's meaning to be anything other than sentimental.

In any case, these are the sorts of reflections I find when I, in blatant defiance of the conventions of so much procreative ethics, consult what has actually been written by parents about their children. The more one reads this literature, which is full of struggle, joy and heartbreak, the more astonishing it seems that philosophers like MacIver and Young cannot see their way to a meaningful distinction between procreation and producing carbon emissions while driving to work. Indeed, the idea that childbearing might be fundamentally about the construction of narratival meaning or existential purpose doesn't even feature in any of the multiple works cited above. This is only possible because theorists have dogmatically chosen to occupy a disengaged, bureaucratic standpoint on human decision-making, the very perspective that sees all practical questions as collapsible into the question of which possible worlds are best.

Importantly, Krause's intimately personal thoughts do not serve to justify a right or permission to procreate, since they are not answers to questions about rights or permissions. They are not meant to stand as a reason for anyone else to procreate, nor are they meant to rebut the claim that significant future sufferings may occur if one has a child. ${ }^{19}$ They are an

\footnotetext{
${ }^{18}$ It appears, for example, in the ancient Epic of Gilgamesh, which is often read as the story of Gilgamesh coming to terms with human mortality. And of course, a great deal of religious belief is very often motivated by consciousness of earthly mortality. One famous hymn, written during the Irish Famine, reads "Change and decay in all around I see; O Thou who changest not: abide with me."

${ }^{19}$ For a systematic treatment of the distinction between reasons for me and reasons for all, see (Hodder 2014).
} 
answer to the existential question, and thus have automatic practical relevance for anyone who finds them compelling. This is why procreative ethicists face an uphill battle. These philosophers wish to bring certain moral-theoretical considerations to bear on the perspective of prospective biological parents, but not only are those considerations of dubious relevance to that perspective, there is almost certainly a different kind of consideration which is immediately practical and authoritative — existential grounding.

\section{Self-Indulgence}

At this point, many committed anti-natalists and pro-natalists will have lost patience. After all, if these ruminations are meant to be decisive, then I am arguing that self-focused existential grounding somehow trumps what we have been calling 'moral' considerationsconsiderations that arise from an impersonal, value-maximizing perspective. Isn't this insufferably self-indulgent?

The first thing to say is that this is not actually my claim, since I am not staking out a positive position in procreative ethics. I am not arguing that.

The choice to have a child is existentially grounding, therefore

It is permissible to have a child.

Existential grounding, as I have said, is not best described as a source of permissions, rights or similar moral claims. Rather, it is simply a weighty practical consideration, one which can be shared with others, but which need not, in every case, be shared with all others. Nor do I claim that the existential question is the only practical question that faces deciding agents; after all, almost all of us care about our moral integrity and about the state of the world more generally. It is not impossible that such considerations might weigh in the decision to procreate, though, as I have suggested, philosophers have not yet shown why they should. The point is that the existential question is quite obviously the sort of question which is of immediate practical significance for a deciding agent.

By contrast, we should remember that if my previous arguments are correct, then the procreative ethicists I have discussed have no solution to the practicality problem, and have therefore not provided anyone with any practical reasons. If their impersonal perspective does not actually speak to the perspective of any deciding agent, it cannot provide reasons which stand in any need of being 'trumped' by existential ones.

However, perhaps the pro- or anti-natalist is not convinced by those previous arguments, and still holds that there is some genuine subjective reason-providing force which arises from their preferred moral perspective. Well, if they can solve this practicality problem, we also need a story about why those reasons are authoritative for agents, why they are sufficiently strong to outweigh other practical considerations. Here, I think, the charge of self-indulgence could have real practical force. Brake, for example, alleges that it would be "narcissistic" to allow personal desires to justify a decision to have children. Few of us wish to be narcissistic, and if childbearing is indeed narcissistic in the thick evaluative sense, then that would be a powerful reason for most of us to avoid it.

However, the existential question is in a way essentially narcissistic. I am unavoidably thrown into a distinct, individual life, a life on which I and only I can 'look back' in the relevant sense, barring bizarre science-fiction scenarios. Put another way, if someone on their 
deathbed is openly asking whether it has all been worth it, there is an absolute, categorical distinction between a person standing beside the bed and the person in the bed. We face the existential question in this unavoidably lonely way. So how can it possibly be narcissistic in any evaluative sense to decide partly on that basis? What is the force of this charge supposed to be?

But surely, it will be insisted, we care about the harm that we do to other persons, and the choice to have a child is the choice to produce such harm and suffering. In choosing to have a child anyway, we are thereby deciding that our own existential predicament is more important than those harms. This, it seems, is unbearably self-indulgent, in a way that might tarnish the existential grounding itself.

But $d o$ we make this comparison, between existential grounding and causing harm? Once again, the abstract, bloodless nature of natalist arguments comes back to haunt their advocates. Let us remember, these are exclusively harms which accrue to either (a) persons who do not yet exist and who can only be harmed if we create them, and (b) future persons who will be affected by large-scale social or environmental catastrophe.

On the first point, we should recall that the oft-cited "non-identity problem" is a problem precisely because there is a huge difference between my harming some existing person and acting so as to create the very person whose sufferings can be traced to me. The fact that the person's very existence depends on my 'harming' them produces an extraordinary puzzle, and it is not at all clear that common-sense terms like "self-indulgent" apply at all to someone who fails to avoid this metaphysically bizarre form of "harming" (Heyd 2009).

On the second point, as I have already indicated, it is virtually impossible for me to make a decision that will prevent large-scale social or environmental ills. It is disingenuous in the least to say that this is at all like an ordinary case of self-indulgence, where existing persons whose welfare I can actually affect are disregarded in favour of self-interested considerations. This is, I fear, yet another case in which language has gone 'on holiday', where a perfectly ordinary term like 'self-indulgent' is being used in a context which is wildly different from the norm.

\section{Conclusion}

Moral philosophy is a tricky business. On the one hand, unless it displays a certain generality, a certain abstraction away from particulars, it isn't philosophy. On the other hand, it often seeks to legislate to particular, situated human agents, informing them that they ought to avoid or pursue various courses of action, that they have various duties and rights, and, increasingly, that certain personal projects they might have are objectively problematic. One of the important lessons of late-twentieth century ethics was that this must be a balancing-act, that questions about practicality and authority cannot be avoided if one is addressing actual agents. Unfortunately, in satisfying what Wittgenstein called the philosopher's "craving for generality", many procreative ethicists appear to have nearly abandoned the particular, and this has led them to provide answers to questions that (almost) no-one is asking. ${ }^{20}$

${ }^{20}$ (Wittgenstein 1958) 


\section{References}

Archer A (2014) Moral rationalism without Overridingness. Ratio 27(1):100-114

Aristotle (2009) The Nicomachean Ethics. OUP, Oxford

Benatar D (2006) Better Never to Have Been: The Harm of Coming Into Existence, vol 32. Oxford University Press, New York

Benatar D (2013) Still better never to have been: a reply to (more of) my critics. J Ethics 17(1-2):121-151

Benatar D (2017) The Human Predicament: A Candid Guide to Life's Biggest Questions. Oxford University press, Oxford

Benatar D, Wasserman D (2015) Debating Procreation: Is it Wrong to Reproduce? Oxford University press, Oxford

Black S, Tiffany E (2011) Why Be Moral. Wiley online library

Brake E (2015) Creation theory: do genetic ties matter. Permissible Progeny? The Morality of Procreation and Parenting:129-149

Collingwood RG (1939) An Autobiography, vol 50. Oxford University press, New York, Etc

Copp D (2008) Darwinian skepticism about moral realism. Philosophical Issues 18(1):186-206

Cutas D (2009) Sex is over-rated: on the right to reproduce. Hum Fertil 12(1):45-52

Dennett DC (2006) Higher-order truths about chmess. Topoi 25(1-2):39-41

Dreier J (2015) Can reasons fundamentalism answer the normative question? Motivational Internalism 167

Edwards P, Freeman E, Sugden SJ (1979) Heidegger on death: a critical evaluation. Hegeler institute La Salle

Frankfurt H (1987) Identification and wholeheartedness. In: Schoeman F (ed) Responsibility, character and the emotions. Cambridge University Press, New York, pp 27-45

Gheaus A (2015) Could there ever be a duty to have children? In: Permissible Progeny?: The Morality of Procreation and Parenting

Heathwood C (2014) Subjective theories of well-being

Heidegger M (1996) Being and time: A translation of Sein und Zeit. SUNY press

Heyd D (2009) The intractability of the nonidentity problem. In: Wasserman D, Roberts M (eds) Harming Future Persons. Springer, Berlin, pp 3-25

Hodder I (2014) The entanglements of humans and things: a long-term view. New literary history 45(1):19-36

Hurley P (2009) Beyond Consequentialism. Oxford University press, Oxford

Korsgaard, C. M. (1996). The Sources of Normativity (Vol. 110): Cambridge University press

Krause E (2017) The things that come around again. In: Gadd A (ed) The magic of motherhood: the good stuff, the hard stuff, and everything in between. Brentwood, TN, Creative Trust Literary Group

MacIver C (2015) Procreation or appropriation? Permissible Progeny, The Morality of Procreation and Parenting, pp $107-128$

McMahan J (2009) Asymmetries in the morality of causing people to exist. In: Roberts MA, Wasserman DT (eds) Harming future persons: ethics, genetics and the nonidentity problem. Springer Netherlands, Dordrecht, pp 49-68

Nagel T (1989) The view from nowhere. Oxford university press, Oxford

Nussbaum MC (1990) "Finely Aware and Richly Responsible": Literature and the Moral Imagination. Oxford University press, Oxford

Overall C (2012) Why have children?: The ethical debate. Mit press, Cambridge

Parfit D (2011) On What Matters. Oxford University press, Oxford

Portmore DW (2008) Are moral reasons morally overriding? Ethical Theory Moral Pract 11(4):369-388

Quigley M (2010) A right to reproduce? Bioethics 24(8):403-411

Robertson JA (1996) Children of choice: freedom and the new reproductive technologies. Princeton University press

Scanlon TM (2014) Being Realistic About Reasons. Oxford University press, Oxford

Scheffler S (1992) Human Morality, vol 43. Oxford University press, Oxford

Scheffler S (1994) The Rejection of Consequentialism: A Philosophical Investigation of the Considerations Underlying Rival Moral Conceptions, vol 100. Oxford University press, Oxford

Singer P (1975) Animal liberation: a new ethic for our treatment of animals. Avon, New York

Smith Iltis A (2000) Bioethics as methodological case resolution: specification, specified principlism and casuistry. The Journal of medicine and philosophy 25(3):271-284

Specter M (1999) The dangerous philosopher. New Yorker 75:46-55

Strawson G (2004) Against narrativity. Ratio 17(4): 428-452 
Street S (2016) Objectivity and truth: You'd better rethink it. In: Oxford Studies in Metaethics, vol 11. Oxford University press, Oxford

Stroud S (1998) Moral overridingness and moral theory. Pac Philos Q 79(2):170-189

Tanyi A (2012) The case for authority. In: Schleidgen S (ed) Should we always act morally? Essays on Overridingness. Tectum

Vavova K (2014) Debunking Evolutionary Debunking. Oxford Studies in Metaethics 9:76-101

Williams B (1981) Persons, character, and morality. In: Rachels J (ed) Moral Luck. Cambridge University press, Cambridge

Williams B (1985) Ethics and the limits of philosophy, vol 83. Harvard University press, Cambridge

Williams B (2000) Philosophy as a humanistic discipline. Philosophy 75(4):477-496

Wittgenstein L (1958) The Blue and Brown Books, vol 34. Harper and row, New York City

Wolf S (1997) Happiness and meaning: two aspects of the good life. Soc Philos Policy 14(01):207

Wolf S, Macedo S, Koethe J, Adams RM, Arpaly N, Haidt J (2010) Meaning in Life and Why It Matters. Princeton University press, Princeton

Young T (2001) Overconsumption and procreation: are they morally equivalent? J Appl Philos 18(2):183-192

Publisher's Note Springer Nature remains neutral with regard to jurisdictional claims in published maps and institutional affiliations. 